\title{
FIREWORKS, FLAGS AND SIGNS: \\ VOICES FROM THE STREETS OF POST-BREXIT BRITAIN
}

\author{
FOGOS DE ARTIFÍCIO, BANDEIRAS E SIGNOS: \\ VOZES DAS RUAS DE UMA INGLATERRA PÓS-BREXIT
}

\section{Sara Roberts, ${ }^{* *}$}

\begin{abstract}
In this article, Sara Roberts, a former BBC researcher and journalist - currently teacher and writer, offers her personal impressions of the recent rise of populism in Britain, based on her experiences in Oxford, where she lives. This essay offers empirical evidence that Brexit has had a profoundly divisive effect on British society from the micro to the macro level, and threatens the very union of nations that makes up the United Kingdom. The campaign for the UK to leave the EU ('Brexit') in the 2016 referendum exploited xenophobic and racist sentiment, thereby creating linguistic and symbolic violence which has managed to pervade popular discourse and consciousness, and which may foreshadow an increase in actual violence. It is suggested here that violence and fear lie at the heart of populism and that all populist movements rely on them, as well as ignorance, to first gain and then maintain support. Acting against the global trend towards populism, the current younger generation; education; civil society and Art are offered as avenues of hope for the future.
\end{abstract}

Keywords: Brexit; populism; nationalism; racism; violence.

\section{RESUMO}

Neste artigo, Sara Roberts, anteriormente investigadora e jornalista da BBC - atualmente professora e escritora, oferece suas impressões pessoais sobre o recente aumento do populismo na Grã-Bretanha, com base em suas experiências em Oxford, onde vive. Este trabalho oferece evidência empírica de que o Brexit tem tido um efeito profundamente divisório na sociedade britânica, do nível micro ao macro, e ameaça a própria união das nações que compõem o Reino Unido. A campanha para o Reino Unido deixar a UE ("Brexit") no referendo de 2016 explorou sentimentos xenófobos e racistas, criando assim uma violência linguística e simbólica que conseguiu permear o discurso e a consciência popular e que pode prenunciar um aumento da violência real. Sugere-se aqui que a violência e o medo estão no cerne do populismo e que todos os movimentos populistas contam com eles, e ainda com a ignorância, para primeiro ganhar e depois manter o apoio. Agindo contra a tendência global para o populismo, a atual geração mais jovem, a educação, a sociedade civil e a arte são oferecidas como vias de esperança para o futuro.

Palavras-chave: Brexit; populismo; nacionalismo; racismo; violência.

\footnotetext{
* d'Overbroeck's College, Oxford, United Kingdom.

** St. Anne's College, University of Oxford, United Kingdom (alumni).sara_1_roberts@yahoo.co.uk Orcid: https://orcid.org/0000-0001-9005-0068
} 
Earlier this year, I heard some fireworks go off in my neighbourhood. It was a few minutes after $11 \mathrm{pm}$ on Friday 31 st January.

At first I couldn't work out where the sound was coming from, or what it was. "What is that?" I wondered, annoyed in case the loud bangs woke up my twoyear-old son. I opened the window and realised that they must be firecrackers and fireworks coming from a couple of streets over in my otherwise quiet working class area. There were woops and cheers, and then, faintly, the sound of people singing 'Rule Britannia', that anthem to Victorian British colonialism.

Then I realised. Of course.

The UK had just left the EU.

"Rule, Britannia! Britannia, rule the waves!

Britons never, never, never shall be slaves."

It is very hard to describe how I felt at that precise moment. Perhaps 'filled with horror and a sense of nameless dread' comes closest to expressing it in words, but really there is no way to adequately convey the leaden, icy sensation that filled the pit of my stomach and spread to the tips of my fingers and toes in that moment, as I realised that my neighbours were celebrating the very thing I had spent my entire day in mourning over.

The next morning disappeared in reading article after article in the newspapers; texting and WhatsApping friends endlessly with despair, rage, black humour; watching TV footage of the EU parliament on YouTube; pacing around my house, thinking, and thinking, and not knowing what to do. I imagine for those of you who are reading this in Brazil - or in the US, or in any number of other places - this may all sound sadly familiar.

In the end, feeling powerless and unable to find the words with which to write, I went and bought dozens and dozens of daffodils, primroses and irises, which I spent the afternoon planting in my garden. Looking out of my kitchen window and seeing the bright splashes of colour against the drab, frozen backdrop cheered me. It comforted me to feel that Spring would come, one day.

This was the only possible positive response I could think of to a political event so momentous and devastating to much of what represents me, and what I represent.

And what is that, I wonder? What do I represent? I suppose, like most things, that probably depends on who you ask.

I am a white British woman, born in Leicester, England, in the early 1980s, part of a leftwing middle-class academic family. But I am also a European, and not 
just in ideology - my mother is French, and so am I. I have double nationality and grew up speaking French as well as English. So I have always been 'different', perched happily on the fence between insider and outsider - a natural diplomat, daughter of two nations sworn to enmity for over a hundred years. "Doubled, not divided," I used to say, to anyone who asked me as a child about where my true loyalties lay.

And yet it's not quite that simple. It's not merely a question of my being Franco-British, or Anglo-French (depending on where you're standing).

I was born in England and I live in England. But my father's side of the family come from Wales - my ancestors were coalminers, almost without exception - and my paternal grandparents grew up speaking Welsh in their small rural community in South Wales. And, historically, it is certainly true to say that the Welsh have no love lost for the English. "Who do you support in the rugby?" my father often gets asked, still. "The Welsh or the English?"

So even within my 'British' side, there is division.

Just as now, at the level of the country, there is division both within and between the different nations that make up this ostensibly 'United' Kingdom. This is not new, I hasten to add, but Brexit has served to exacerbate an existing situation, and has opened the lid and shone a spotlight on this particular festering can of worms, making it plain for all to see and impossible to deny. Indeed, as the internationally renowned British author Ian McEwan (2020) wrote in his article in The Guardian on Saturday 1st February, Brexit has drawn new maps of the country, with fault lines running in unexpected directions. It has revealed our "gift for multiple and bitter division - young against old, cities against the country, graduates against early school-leavers, Scotland and Northern Ireland against England and Wales". It's not just the class rift that separates us from our fellow compatriots: it turns out, we have a talent for division.

Again, some of this may sound sadly familiar.

What will happen, I wonder, if Scotland really does secede and finally gain its independence? And what about Northern Ireland? They both voted to remain in the EU, after all, and may yet jump ship to leave Britain and join Europe again. What shall we call ourselves then? 'The Dis-United Kingdom of England and Wales'? Given that, as I mentioned earlier, many Welsh people have no love lost for the English - to put it mildly - 'Dis-United' might seem the best description. Apart from any other practical, political or economic considerations, we do need to start thinking about a new name for what remains of the country: surely the word 'United' could have no place in the title of such a Kingdom. This is a matter of grave 
concern to me, and I do hope that Boris Johnson's government has a department dedicated to it. Perhaps next-door to the one dedicated to changing the colour of British passports to blue, so that they look different from the dark red EU passports. Yes, really - this is not a joke, though it may sound like something from a Monty Python sketch. Also not a joke is the fact that the contract for manufacturing these new, super-symbolic, blue British passports was awarded to a European company because to do so would "save taxpayers about $£ 120$ million" (WALKER; STEWART, RAWLINSON, 2018) in comparison with its British competitor, De La Rue.

What else is there to say, then?

I remember these lines of T.S. Eliot:

\footnotetext{
"Words strain,

Crack and sometimes break, under the burden,

Under the tension, slip, slide, perish,

Decay with imprecision, will not stay in place,

Will not stay still."
}

When language is most stretched by reality - by the absurdity or the horror of it - is when we turn to poetry. Art in general of course - music, dance, painting. All of them, not just poetry. But especially poetry, in my experience. It's something about the words. The way they manage to express something beyond themselves, beyond the sum of their parts.

And with Brexit, we have all acquired a new lexis. This begins with the word itself: an ugly, and lazy, neologism, it is a portmanteau of the words 'Britain' - or 'British' - and 'exit'. It "caught on," as Benjamin Mueller (2020) writes, "as shorthand". It has since been followed by endless jargon, a torrent of technical names and phrases, formerly the territory of bureaucrats and legislators, now opened up to the general population with strange effect. Other terms were invented by politicians to try and make complex things seem simple. As McEwan (2020) says, "We acquired an argot. 'Article 50', 'frictionless trade', 'just in time', 'the backstop' - how they tripped off the tongue. We learned to respect an 'invisible border'. Before it all began, only a very few knew the difference between the customs union and the single market."

The way we speak and write, the language we use, has changed.

And language, as we all know, is a territory.

On home territory, with my family, I speak Spanish and English mainly, though French with my mother. My partner is Spanish, from Galicia, and our toddler understands all three of his 'heritage' languages: English, Spanish and French. (We 
did consider teaching him Welsh and Galician as well, but decided that it might not be entirely practical.)

We are a trilingual, multi-cultural, European family then, living in a working class area of Oxford, one of the most prosperous and highly educated cities in the UK, but also one of the most unequal (OXFORD CITY COUNCIL, 2019). We get on well with our neighbours, yet they celebrated an event that for us was a subject of mourning, and for me personally felt much like what Roger Cohen describes in his excellent and beautifully written piece in The New York Times, Requiem for a Dream. Writing on 31st January, he describes how he felt "orphaned" by Britain's departure from the European Union. "I've lost a limb; more than a limb, my heart," he writes. This is a sentiment I can understand.

What I cannot understand, no matter how much I try, is why my neighbours would genuinely celebrate the same event. What is it, exactly, that they believe they are celebrating?

I may read many words, by scholars or journalists or analysts, explaining it, but I find myself unable to comprehend. Not because I'm unable to understand the arguments, but because I can't understand the feelings. I try. I remember Atticus Finch's line in To Kill A Mockingbird: "You never really understand a person until you consider things from his point of view... until you climb into his skin and walk around in it." And I try. But with no effort of the imagination can I think myself into their shoes. I can't understand, emotionally, what they are feeling. I can't empathise. And that - both on a personal and a societal level - frightens me. It signifies the ultimate breakdown, not only in communication, but also in civility. In humanity. It is too easy to dismiss or dehumanise those we cannot empathise with.

Here, of late, signs have become more important.

Or, at least, more visible.

I don't mean 'sign' in the Saussurean sense. Though that as well, for sure. (In fact, Saussure, Foucault, Derrida and Lacan would have so much linguistic material these days that they wouldn't know where to look.)

Nor do I mean 'sign' in the Dan Brown, conspiracy theorist sense (though surely some of them may also be bad omens.)

No. I mean 'sign' as in, quite literally, the physical object. A piece of paper or cardboard, metal or cloth, printed or painted or daubed with numbers, letters, pictures. Symbols of one kind or another. Instructions. Images.

Posters.

Flags.

Bumper stickers, even, on the back of the car in front. 
They are all signals, advertising a belonging to a particular tribe.

In the context of Brexit - and given how the referendum campaign became coopted by anti-immigration discourse - these signals are intended to say, either: "You are welcome here" or "Go away." They are aimed at "The Other' (in this case, the perceived Foreigner) and they convey acceptance or rejection. Of strangers, neighbours, colleagues. Friends. Visitors. The impact, for a society as cosmopolitan and diverse as Britain's today, is irrevocably divisive and the damage done - to individuals' feelings and sense of identity, to friendships, families, communities, workplaces, indeed to the country as a whole and its image abroad - is often irreparable.

Two friends of mine who have been living in London for many years were shocked and horrified when, in the run-up to the referendum in 2016, their immediate next-door neighbours on either side of the house they had just bought put up posters in their front windows. The posters said things like: 'Let's Take Back Control of our Borders', 'Stop immigration' or, even, 'Go home'. The latter is a common phrase which carries particular baggage when aimed - as it often is - at people for whom 'home' is here; people who in some cases were born here.

One particularly infamous poster belonging to the official 'Vote Leave' campaign showed a smirking Nigel Farage standing in the foreground in front of a huge queue of people who look like they might be refugees from a country such as Syria or Iraq. In large red print, the text reads: 'BREAKING POINT. The EU has failed us all.' The image was severely criticised by many at the time for deliberately conflating and confusing the issues of legal immigration from the EU and illegal immigration from other countries, as well as for dehumanising the people involved.

My friends, Fabio and María (not their real names), felt as if the posters were targeted at them and suddenly didn't know how to behave with their neighbours. They felt wounded. Yet their neighbours did not seem to realise, at all, that their actions might affect Fabio and María and hurt their feelings. They continued to act as normal, to them, 'The Other' was somebody else. A faceless person, or a faceless multitude, but certainly nobody they knew personally and liked.

To give a little context: Fabio is an Italian academic - a progressive economist working mainly on Latin America at a leading university in London - and María is a medical researcher from El Salvador, working in cancer research for the British National Health System (NHS). Both of them are working, paying their taxes, and making valuable contributions to British society in a range of different ways. They have both been in the UK for a long time and feel settled here. Or at least, they did until the word 'Brexit' suddenly came into existence, first of all, and then took on 
a monstrous life of its own. Their neighbours' posters put everything into question for them, including the safe place they had considered their home.

Stories like theirs abound, of course. They are not, unfortunately, an isolated example.

Flags, too, have become more visible of late.

A video springs to mind of Nigel Farage waving miniature British (the socalled Union Jack) flags in the European Parliament on 29th January at the end of his gleeful 'farewell speech'. "It's globalism against populism," he said, "And you may loathe populism, but I'll tell you a funny thing," he went on, smirking in advance at his own joke, "... it’s becoming very popular!" Around him, his supporters laughed, hyena-like, as if he had said something tremendously funny and clever.

And at the end of the pitiful, nose-thumbing taunt to the Parliament that had paid his salary for years (indeed he was the seventh highest earning of all MEPs, see RANKIN, 2018), instead of sticking his tongue out, Farage and his followers whipped out the miniature British flags that they had hidden, in contravention of the rules, to "wave" the EU Parliament "goodbye". In response, the Irish vicepresident of the Parliament, Mairead McGuinness, switched off his microphone, so for a moment Farage was left opening and closing his mouth in silence, like a fish. "Could we please remove the flags?" McGuinness said, sternly. His supporters ignored her, continuing to clap and cheer. "Put your flags away, you're leaving," she said, and the disdain of centuries was in her voice as this Irish woman said to this English man, "And take them with you, if you are leaving now." At this, the entire European Parliament erupted into laughter, applause and cheering. "Goodbye," she said. She did not say 'good riddance' but she may as well have. The words hung, almost visible, upon the air. As Roger Cohen (2020) writes, "An Irish woman from a country uplifted by European Union membership [the Republic of Ireland] reprimanding the new breed of little-England male as he exits history in pursuit of an illusion: the symbolism was perfect."

Generally, though, I can't help thinking that the Union Jack flag is a rarer sight these days, at least in terms of its visibility on the streets. Not that it was ever particularly visible, beyond official buildings. Unlike in many other countries, it is not usual in the UK - outside of the World Cup or other international sporting events - for people to hang any kind of national flag from their houses.

The Union Jack is supposed to visually represent the unity of the Kingdom of Great Britain and Northern Ireland: its design is a superimposition of the English flag, the Scottish flag (the white saltire of St. Andrew, on a blue background) and the red saltire of St Patrick, to represent Northern Ireland. Interestingly, the Welsh 
flag of the red dragon is not included, because at the time the first Union Flag was created, Wales was just a Principality annexed to the English crown, rather than a Kingdom in its own right. (A few clues as to historical exclusion and resentment right there.)

But a different flag has been appearing lately in the streets around where I live. It is the Cross of St. George: the English flag. A simple red cross on a white background. Where the 'Union' Jack symbolises the unity of the whole Kingdom, the Cross of St. George represents the opposite. England, England, and only England. Until recently, it was at best perceived as the favoured sign of 'little Englanders', at worst skinheads and neo-nazis. In the past, if I saw one, I would probably have crossed the street. Now, in my neighbourhood, it is proliferating. It hangs over the door of the pub on the corner, which - as relatively new residents we had been meaning to go to. Now, I make a mental note to avoid the place: it is signalling itself as hostile territory. As I drive past on my way to work, I count the crosses that I see, and re-draw the map of the area in my mind.

In this context, it was a welcome surprise to see on Saturday 1st February, an enormous European flag hanging over the front of a house, a little further away from where I live. I have rarely ever felt moved by a flag, but on that morning my mother and I both felt moved to go and ring the doorbell of the house to thank the person for warming us with the sight of it. A young woman opened the door, holding a baby. She looked scared. "We saw your flag and we just wanted to say thank you." Relief flooded her face. She smiled. "Oh God, I thought we might get a brick through the window," she said. "What with being opposite the Conservative club and everything."

Another recent sign that I think is worth mentioning, is an anonymous poster entitled 'Happy Brexit Day' (see Figure 1) that appeared on all 15 floors of a block of council flats in Norwich the day Britain officially left the EU, Friday 31 st January. The poster, which has since gained notoriety on the internet, was stuck up on all the fire doors in the building and was investigated by police as a racially aggravated incident, believed to have been aimed at Polish residents (see WEAVER, 2020). 


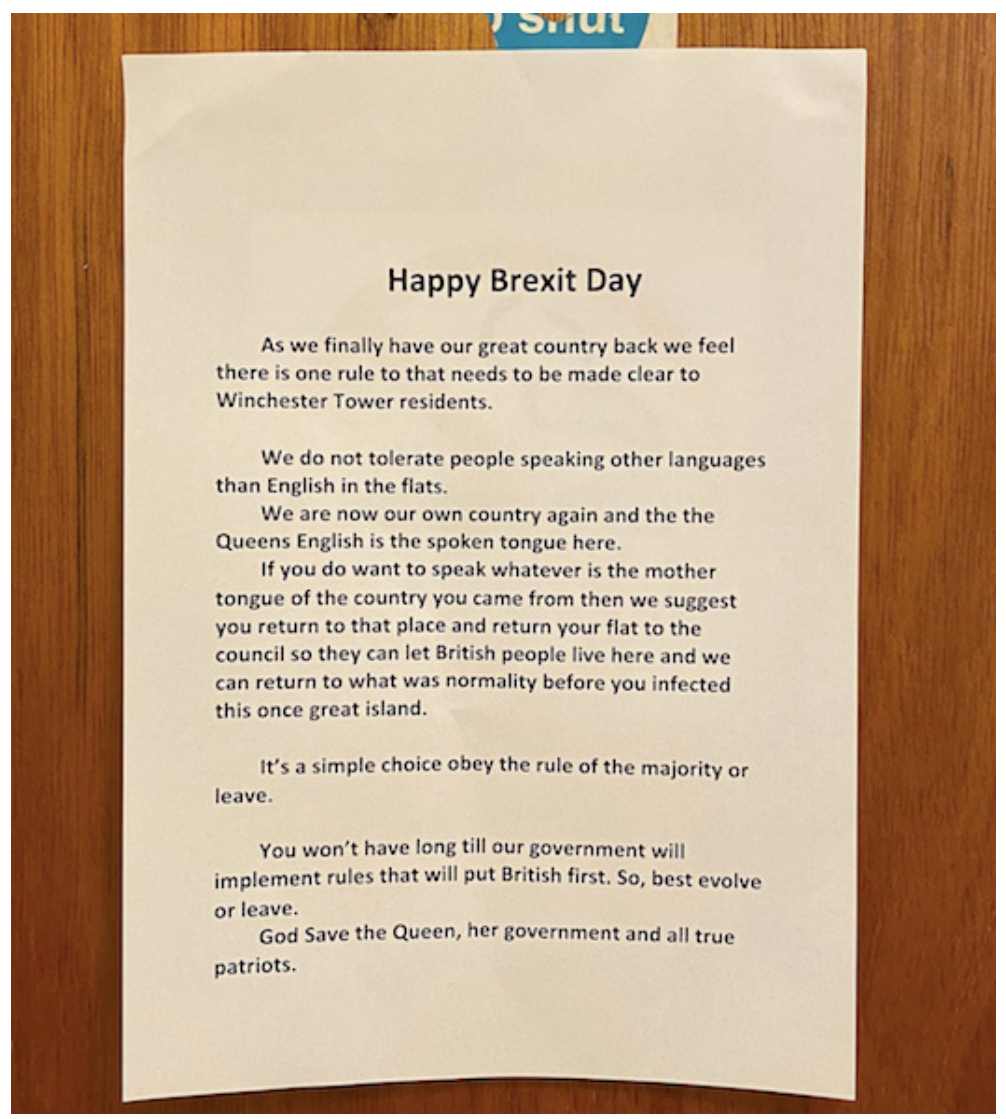

Figure 1. Brexit poster seen in a block of flats in Norwich. Photograph: Anonymous via Twitter

I used this image as the starter activity with every one of my teaching groups that week. "Identify three things that you think are wrong with this poster," I said. Their responses were incredible. My students scrutinised the text, with all its ugliness, typos and basic errors of punctuation, and all of them without exception from the youngest at 11 years old, to the oldest at 18, recoiled in horror at its message. "Who is the 'we'?" they asked. "The 'we' in 'We do not tolerate'? And how do we know it's not just an 'I', some lone weasel, acting alone and trying to pretend that there are more of them?" We talked about how the poster must have made the residents feel when they saw it. How different people might have reacted - young people, old people, parents with young children. And my students all said, "It would make you feel afraid." "It would make you wonder, 'Or what?" one 15-year-old boy said. "We mustn't speak any language here other than English... or what? What are you going to do about it?" In the end, they decided, it was the 
words than were unwritten that created the most fear. It was the space around the words. The implicit threat of violence. The unspoken.

Because really, at its heart, populism depends on two things for its lifeblood - violence (or the threat of violence, implicit or explicit) - and fear. Of the two, fear is the greater enemy. It is harder to combat, because it is more infectious, and it is insidious. As for the violence, where does it come from, this simmering violence in otherwise seemingly peaceful countries? Clearly it stems from anger, whether justified or not. But it is anger that has been manipulated and misdirected.

That same anger - the crystallisation of decades if not centuries of resentment - can be, in my mind, the only explanation for what happened in Wales. Because it was precisely those same small, rural, mining (or post-mining) communities in Wales - like the ones my grandparents came from - where the 'Leave' vote won out most strongly in the referendum in 2016. The ones whose economy Thatcher destroyed with her closure of the mines, or who have been devastated by the decline in the steel industry. Since then, they have been scorned or simply ignored by successive Westminster governments. 'Out of sight, out of mind' - and they are indeed far away, and invisible to the political elites of London. It is understandable that people there are angry: "the West Wales and the Valleys region was identified as the poorest $[\ldots]$ in the whole of north-western Europe" (CADWALLADR, 2016). There are Welsh villages and small towns, like Ebbw Vale, where unemployment is nearly 40\% (CADWALLADR, 2016).

Yet in these areas the EU flag is visible all over the place... on signs and plaques, recognising the source of funding for this road, that bridge, train station, railway line, community college, leisure centre, football pitch. These are areas that have had truly huge amounts of European money poured into them. Ebbw Vale received more investment from the EU "than perhaps any other small town in Britain" (CADWALLADR, 2016). Yet 62\% of the population - the highest proportion in Wales - voted Leave.

Why? Why on earth would communities like these vote to leave the EU, in light of this?

It is the same question as: "Why on earth would a working class black woman, say, for example, vote for a man like Jair Bolsonaro?"

It is what Ian McEwan calls the "magic dust" of populism that has been thrown into our eyes to blind us.

So how do they do it? What is their recipe for this blinding success? It has its own 21 st-century iteration, but essentially it hasn't changed much. It's a tried-and-tested method, as history will testify: Plenty of money to pay for political 
campaigns, a largely sympathetic media, use of highly persuasive, emotive, divisive, and simplistic language to whip people into a frenzy. A certain amount of creativity with information (no need to feel bound by numbers - if in doubt, just make them up). A scapegoat (the Jews, Trotsky, immigrants, the EU - whatever you have to hand). A healthy (or unhealthy) dose of nostalgia, ideally relating to a colonial past. An unshakeable belief in one's own special status as a nation set apart from all others. And finally, a large enough proportion of the voting-aged population that is easy to manipulate due to being poor, uneducated, prejudiced, fearful, or angry.

That's all a populist needs to orchestrate a spectacular rise to power, even in a place like the UK: a supposedly boring, stable and mild-mannered, well-established democracy full of highly educated political moderates. Ha.

"The thing is, you see," the taxi driver tells me, "He's like one of us." He's speaking about Boris Johnson. ("No he's not!" I shout inwardly. "He's really not! I promise!") "He went to Eton," I say. "Why do you believe that he's not part of the elite?" The taxi driver thinks about this for a minute. "He sounds like me," he says finally. "He speaks the way I do... I understand him when he talks." There it is, then. It all comes back to language in the end.

So where do we go from here? What will be the next signs we will see? Graffiti sprayed on walls, paint daubed on shop windows? Will non UK-born residents be required to start wearing a red triangle sewn onto their clothing? Well...

We all know where that sentence ends.

And here in Europe, - yes I know what you're thinking, but we are still in Europe - just look at any map and you will see the undeniable evidence that, though we may have left the European Union, whether we like it or not, the continent in which this small, strange little island is located is most definitely Europe, and there can be no chance of us leaving that any time soon.

So let me begin my sentence again.

Here in Europe, the spectre of the Holocaust rises, ghost-like and inevitable. The collective trauma of the Second World War is a terribly European inheritance. It lurks in the shadows, barely concealed behind our conversations, our black humour and our attempts at irony.

My Polish friend, a zoologist working for an eminent British university, told me recently that she had applied for British citizenship, simply because she didn't trust the government not to revoke her post-Brexit "settled status" one day, at some undefined time in the future. "I'd rather just take on the nationality," she said. "At least then they can't touch me. With the settled status, all they'd have to do is pass a law. It would be easy - just the flick of a switch, and we'd all be made illegal." 
I nod, as we push our toddlers on the swings. I have been teaching The Handmaid's Tale for years. She doesn't need to explain.

Linguistic violence - the violence of signs and symbols - culminates in actual violence. This is not breaking news: Émile Durkheim first published The Rules of Sociological Method in 1895 (see DURKHEIM, 1985 [1895]). Many scholars have studied the stages of violence. I am not a scholar, and my own understanding of the theory behind it is limited. However, in my experience, something first has to become thinkable before it can become writable, then sayable, and finally doable.

The vice-president of the EU Parliament, Mairead McGuinness, showed a striking awareness of this when she added, as a final reprimand to Farage's goodbye speech in the European Parliament - while he and his acolytes were packing up their things and leaving - "If I may say, [...] the word 'hate' was used in the last contribution, and I really think [...] that we should not bate any one, or any nation, or any people." Again, there was applause from the other members of parliament. Here is an Irish woman who clearly knows the power of words to incite acts of hatred.

Because acts of symbolic violence, linguistic violence, become acts of physical violence enacted, perpetrated, against people. People end up getting hurt - first their feelings, then their bodies. People are injured, killed. But no act of violence comes out of nowhere. Liisa Malkki (1995) wrote about this in relation to the Rwandan genocide of 1994. History has shown it to be true, again and again.

In case we needed a reminder, though:

In the week following the United Kingdom voted to leave the European Union (the "Brexit") on June 23 , there was a $500 \%$ rise in hate crimes across the country. Examples, such as racist materials sent in the mail, barked epithets on the street, and demands directed at foreigners and non-white citizens to leave the country, have been collected on social media under the hashtag \#PostRefRacism.

This is the opening paragraph of an online article by Ray Drainville. It appears beneath a photo posted on Twitter on 5 July 2016, soon after the referendum. The photograph shows the wall of an NHS Health Centre. The graffiti reads: EU RATS GO HOME NOW.

Seeing the image, I get that same cold feeling again. It feels like a nightmare. It feels unreal. Where am I? What is happening? I do not recognise this place.

Gina Miller, the Guyanese-British business owner and now world famous legal activist, has challenged the British government twice in the courts in recent years. First, unsuccessfully, over the government's authority to implement Brexit without approval from Parliament. The second time, successfully, last year over the 
government's prorogation of Parliament. It was a historic victory for democratic institutions everywhere. But Miller described the abuse she received as a result, and it is shocking. She told the newspaper The Guardian: "On a personal level, the abuse was much worse this time. Most notably the men standing outside the supreme court with a noose, with posters calling me a traitor, who were present throughout the entire case. I had to enter and leave each day through the throng shouting 'hang her', 'send her back home'. As I quickly tried to get into my security car one day, they broke ranks, reaching the car doors and yelling: 'Cut her filthy tongue out.' The police should never have allowed them to be there. They said it was freedom of speech, but inciting violence [...] is a criminal offence."

Other than lamenting the situation, what can be our response to this increase in verbal violence, which inevitably accompanies the recent rise in populism?

My friend, who is a lawyer, tells me that she is saying affirmations to herself in the mirror every morning and using positive visualisations about the future. It may well be beneficial. But if this were the Cretaceous period, then (to use McEwan's metaphor) surely we would be the herbivores. Boris Johnson, Nigel Farage and their ilk would be... well, not Tyrannosaurus Rex, certainly. There is nothing of that majesty to them. But perhaps Velociraptors - opportunistic pack hunters, sharpeyed, sharp-toothed, and cunning. I would like to consider myself an optimist, but I am not convinced that the future belongs to the herbivores.

I think back to those kids in my classroom. They all, irrespective of political leanings or belief systems, irrespective of age or gender, could see with complete clarity that hate was not the way forward. Instinctively, they knew that demagogues like Johnson, Farage, Trump or Bolsonaro were, firstly, full of lies, and secondly, dangerous for the future (and indeed the present) of our world. Will we have to wait until they all come of voting age? Or however long it takes for the worst bigots currently active in politics to die off or retire? And what do we do in the interim?

Well, in the interim we have our affirmations and visualisations. We have a certain number of institutions, civil society, checks and balances. We have people like Gina Miller and Lady Brenda Hale. International Human Rights Law and lawyers who work tirelessly to uphold it. We still have newspapers like The Guardian and The New York Times. We have teachers and academics, and wonderful universities. We have artists and writers and musicians. Voices of dissent can still make themselves heard. My country is increasingly unrecognisable territory to me, but these things still exist, and they separate us from the abyss. We must prize them and nurture them preciously. And we must hope that that will be 
enough to keep the violence of this populism in the realm of the linguistic and symbolic, and out of the physical.

"For last year's words belong to last year's language And next year's words await another voice."

T.S. Eliot, Four Quartets

\section{REFERENCES}

ATWOOD, Margaret. (1985). The Handmaid's Tale. Toronto: McClelland \& Stewart.

CADWALLADR, Carole. (2016). View from Wales: town showered with EU cash votes to leave EU. Available at https://www.theguardian.com/uk-news/2016/jun/25/viewwales-town-showered-eu-cash-votes-leave-ebbw-vale Access on February, 2020.

COHEN, Roger. (2020). Requiem for a Dream. Available at https://www.nytimes. com/2020/01/31/opinion/brexit-uk.html Access on January, 2020.

DRAINVILLE, Ray. (2016). The Visual Propaganda of the Brexit Leave Campaign Available at https://hyperallergic.com/310631/the-visual-propaganda-of-the-brexitleave-campaign/ Access on February, 2020.

DURKHEIM, Émile. (1985 [1895]). The Rules of Sociological Method. Edited by Steven Lukes. Translated by W. D. Halls. London: The Macmillan Press.

ELIOT, T.S. (1941). Quartet No. 1: 'Burnt Norton' and Quartet No. 4: 'Little Gidding’, Part II. In: Four Quartets. New York: Harcourt, Brace and World.

KHAN, Shehab. (2018). Final Say: The misinformation that was told about Brexit during and after the referendum. Available at https://www.independent.co.uk/news/uk/politics/ final-say-brexit-referendum-lies-boris-johnson-leave-campaign-remain-a8466751. html\# Access on February, 2020.

LEE, Harper. (1960). To Kill A Mockingbird. Philadelphia: J. B. Lippincott \& Co.

LICHFIELD, John. (2017). Boris Johnson’s £350m claim is devious and bogus. Here’s why. Available at https://www.theguardian.com/commentisfree/2017/sep/18/borisjohnson-350-million-claim-bogus-foreign-secretary Access on February, 2020.

LISTER, Sam. (2016). EU referendum: Vote Leave faces criticism over Turkey 'criminals' claim. Available at https://www.independent.co.uk/news/uk/politics/eu-referendum- 
vote-leave-faces-criticism-over-turkey-criminals-claim-a7041876.html Access on February, 2020.

MALKKI, Liisa H. (1995). Purity and Exile: Violence, Memory, and National Cosmology among Hutu Refugees in Tanzania. Chicago: Chicago University Press.

McEWAN, Ian. (2020). Brexit, the most pointless, masochistic ambition in our country's history, is done. Available at https://www.theguardian.com/politics/2020/feb/01/ brexit-pointless-masochistic-ambition-history-done Access on February, 2020.

McGOWAN, Mary Kate. (2012). On 'Whites Only’ Signs and Racist Hate Speech: Verbal Acts of Racial Discrimination. In Mary Kate McGowan Ishani Maitra (ed.), Speech and harm: Controversies over Free Speech. Oxford University Press.

MERRICK, Rob. (2017). Brexit: Vote Leave chief who created $£ 350 \mathrm{~m}$ NHS claim on bus admits leaving EU could be 'an error'. Available at https://www.independent.co.uk/ news/uk/politics/brexit-latest-news-vote-leave-director-dominic-cummings-leaveeu-error-nhs-350-million-lie-bus-a7822386.html Access on February, 2020.

MUELLER, Benjamin. (2020). What Is Brexit? And What Happens Next? Available at https://www.nytimes.com/interactive/2019/world/europe/what-is-brexit.html Access on February, 2020.

OXFORD CITY COUNCIL. (2019) Poverty and deprivation across Oxford have reduced but the city remains starkly unequal - new figures. Available at https://www.oxford. gov.uk/news/article/1245/poverty_and_deprivation_across_oxford_have_reduced_ but_the_city_remains_starkly_unequal__new_figures Access on February, 2020.

RANKIN, Jennifer. (2018). Nigel Farage seventh on list of MEPs' outside earnings. Available at

https://www.theguardian.com/world/2018/jul/10/nigel-farage-seventh-on-list-of-mepsoutside-earnings Access on February, 2020.

READ, Jonathon. (2017). Politicians dismiss return of blue passports as 'insular nonsense'. Available at https://www.theneweuropean.co.uk/top-stories/politicians-criticise500-million-pound-blue-passports-1-5333053 Access on February, 2020.

SAUL, Jennifer. (2017). Habituation and Hate. Available at https://www.huffpost.com/ entry/habituation-and-hate_b_9449748? guccounter $=1 \backslash$ 
WALKER, Peter; STEWART, Heather; RAWLINSON, Kevin. (2018). New blue UK passports will be $£ 120 \mathrm{~m}$ cheaper if made in Europe. Available at https://www. theguardian.com/politics/2018/mar/22/contract-to-print-uk-passports-abroad-willsave-120m Access on February, 2020.

WEAVER, Matthew. (2020) 'Speak only English' posters racially aggravated, say police. Available at https://www.theguardian.com/politics/2020/feb/01/police-called-inafter-poster-tells-residents-of-flats-to-speak-english Access on February, 2020.

Recebido: $15 / 03 / 2020$

Aceito: 8/04/2020

Publicado: 9/04/2020 